\title{
SGPP1 Gene
}

National Cancer Institute

\section{Source}

National Cancer Institute. SGPP1 Gene. NCI Thesaurus. Code C105037.

This gene is involved in sphing osine-1-phosphate degradation. 